Sharif University of Technology
Scientia Iranica
SCIENTIA

Research Note

\title{
Advanced exergy and exergoeconomic analyses of Kalina cycle integrated with parabolic-trough solar collectors
}

\author{
F.A. Boyaghchi* and M. Sabaghian \\ Department of Mechanical Engineering, Faculty of Engineering and Technology, Alzahra University, Deh-Vanak, Tehran, P.O. Box \\ 1993891176 , Iran.
}

Received 24 December 2014; received in revised form 22 September 2015; accepted 20 October 2015

KEYWORDS
Solar energy;
Endogenous/exogenous;
Unavoidable/avoidable;
Kalina cycle;
Modified exergy
efficiency.

\section{Introduction}

In recent decades, the energy demands all over the world have been increasing dramatically and because of the harmful effects of global warming, the environmental issues have gained importance. Thus, investigating more efficient energy conversion systems, use of renewable energy, and enhancement of the performance and efficiency of existing energy systems have become the priorities. To reach these aims, one of the best strategies is renewable energy conversion by using new efficient cycles, such as Kalina cycle. Kalina cycle was first presented by Kalina [1] in 1982. This

\footnotetext{
*. Corresponding author. Tel.: +982188044040-2140; Fax: +982188041469

E-mail addresses: aboyaghchi@gmail.com \&

fahmadi@alzahra.ac.ir (F.A.Boyaghchi)
}

\begin{abstract}
This research deals with the performance and cost assessment of a Kalina among system components. The exergy destruction rate and the total operating cost within , of which $32 \%$ is related to the components and $68 \%$ is due to the interaction rate is associated with endogenous cost rate $\left(\dot{Z}^{E N}\right)$ and $84 \%$ of the avoidable investment cost rate $\left(\dot{Z}_{D}^{A V}\right)$ is endogenous. It is revealed that the auxiliary heater and PTSC have the (C) 2016 Sharif University of Technology. All rights reserved.
\end{abstract}

cycle operates by using an ammonia-water mixture as the working fluid and because of its low boilingpoint temperature, it can be used as a procreate cycle for using low-temperature heat sources and renewable energy, such as solar energy.

Lately, some research has been allocated to Kalina cycle, employing the low-grade heat source [2] and the geothermal energy [3-8], applied as bottoming power cycles [9-11] and solar energy by integrated flat plate solar collectors [12-15], PTSCs [16-18], compound parabolic collector [19], and central receiver [20].

Although exergy analysis is a powerful tool for development, evaluation, and improvement of an energyconversion system, it is not much prevalent among energy practitioners, because of the lack of a formal method in using the outcomes obtained by an exergy analysis, so that a formal method cannot be progressed as long as the interactions among elements 
of the system are not taken perfectly into account. A conventional exergetic or exergoeconomic analysis cannot appraise the mutual interdependencies among the system elements. It is achievable in an advanced exergetic analysis. The exergy destruction in each element is divided into endogenous and exogenous parts in advanced exergetic analysis. Additional dividing of the exergy destruction in each element to the avoidable and unavoidable parts enables a realistic appraisal of the potential for improvement. Also, the combination of these two splitting approaches lets the designer of an energy system with unambiguous and important detailed data about options to improve the overall efficiency.

In the literature, there are not many papers about advanced exergy and exergoeconomic analyses of power generating systems.

Some research has been allocated to advanced exergetic analysis of gas turbine system [21-23], cogeneration system that combines vaporizing liquefied natural gas with the generation of electricity $[24,25]$, combined cycle power plant [26-28], coal-fired power plant [29,30], trigeneration system with a diesel-gas engine operating in a refrigerator plant building [31], ejector refrigeration system [32], multi-effect evaporationabsorption heat pump desalination [33], geothermal power plant [34], and a ground-source heat pump dryer [35]. Also, some researchers have applied the advanced exergoeconomic analyses to assess the cogeneration system [36,37], externally fired combined cycle power plant [38], geothermal power plant [39], combined cycle power plant [40], geothermal district heating system [41], electricity-generating facility with natural gas [42], multi-effect evaporation-absorption heat pump desalination [33], refrigerant natural gas liquefaction processes [43,44], building heating system [45], and Gas Engine Heat Pump (GEHP) for food drying processes [46].

In this paper, a Kalina power cycle integrated with PTSC is proposed, modeled comprehensively based on Ref. [47], and analyzed for the first time using an advanced exergoeconomic analysis method. The improvement potential of the system is determined using the relationships between investment cost rates and exergy destruction cost rate; then, possible approaches are identified to determine the reasons of exergy destruction and develop economic parameters of the system.

\section{System description}

A schematic diagram of the system is shown in Figure 1. The system is divided into three subsystems: Kalina cycle, temperature stabilized, and solar collector.

\subsection{Kalina cycle subsystem}

Kalina cycle includes a separator, a turbine, an evaporator, a mixer, a pump, a Low-Temperature (LT) recuperator, a High-Temperature (HT) recuperator, and a condenser. The ammonia-water mixture, which has varying boiling and condensing temperatures, is used as the working fluid of this cycle. The ammoniawater mixture is heated in the evaporator by absorbing heat from solar collector subsystem (points 1-2). Then, it enters the separator (point 2). The relatively rich solution of ammonia-water is separated from the liquid phase in a separator and it leaves the separator as saturated vapor (point 3). Afterwards, it passes through the turbine (point 5) and generates power.

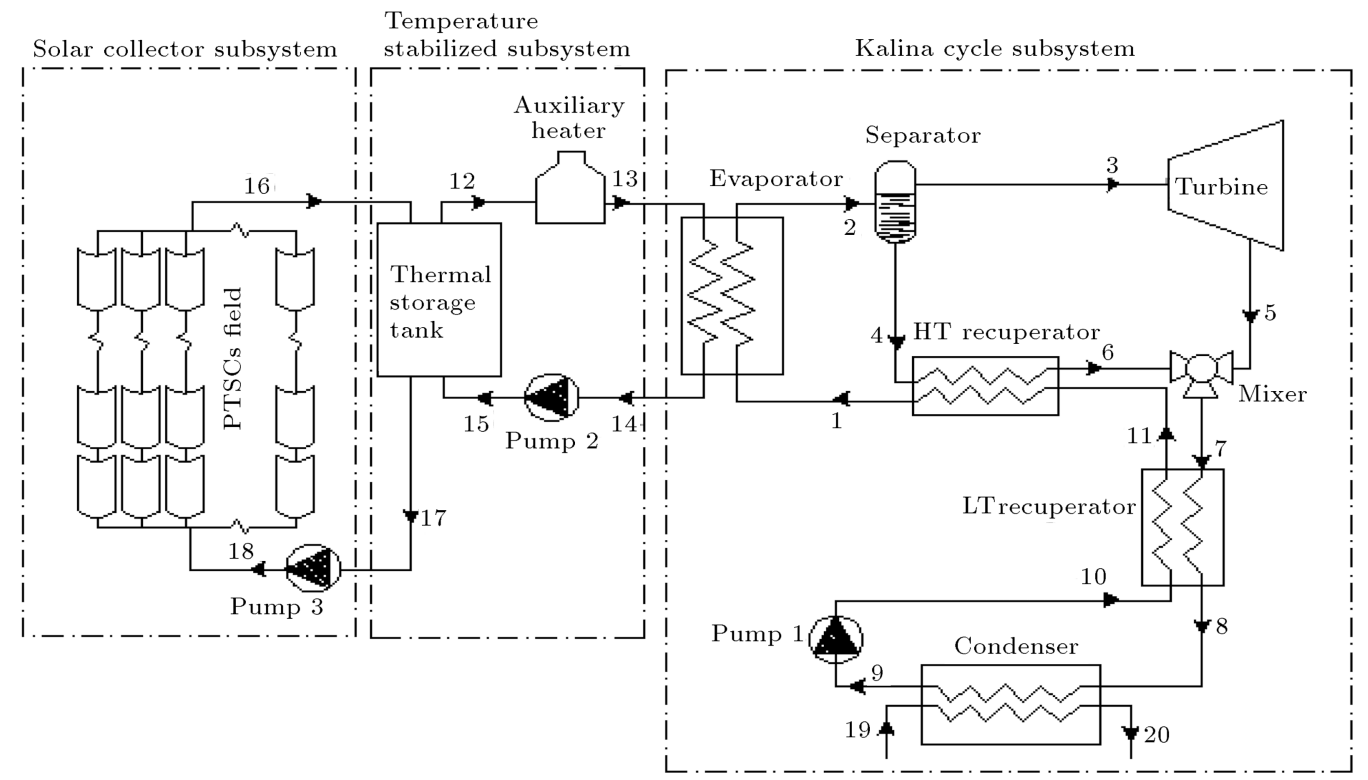

Figure 1. Flow diagram of the Kalina cycle operated by solar energy. 
Saturated liquid of weak solution leaves the separator (point 4) and heats another flow by passing through recuperator (points 4-6). The steam flow (point 5) and liquid flow (point 6) are merged together in mixer to form the ammonia-water basic solution (point 7). After being cooled down in LT recuperator (point 8), the mixture is condensed to liquid phase of ammonia-water (point 9) in the condenser by cooling water (points 1920 ). Then, it is pumped (point 10) into evaporator after preheating through the LT recuperator (points 10-11) and HT recuperator (points 11-1).

\subsection{Temperature stabilized subsystem}

Temperature stabilized subsystem includes a thermal storage tank, an auxiliary heater, and a pump. Therminol $V P-1$ oil is used as the working fluid of this cycle because of its stability in high temperature and good heat transfer properties. Therminol $V P-1$ heats the ammonia-water mixture by passing through the evaporator (points 13-14) and then it is pumped to the thermal storage tank (point 15). The thermal storage tank is operated to stabilize temperature of the fluid when solar radiation is not sufficient; in addition, an auxiliary heater is installed as the backup energy source to increase the temperature of the working fluid when it, at the outlet of the thermal storage tank (point 12), drops below the allowable temperature to supply the required temperature of fluid in the inlet of evaporator (point 13).

\subsection{Solar collector subsystem}

Solar energy collector subsystem includes a pump and the PTSC filed. Therminol $V P-1$, as the working fluid, is pumped to collectors (point 18) and it absorbs the solar energy (point 16) to supply the required energy of temperature stabilized subsystem. Table 1 indicates the specifications and design parameters of solar Kalina power plant.

Table 1. The specifications and design parameters of solar Kalina power plane.

\begin{tabular}{|c|c|}
\hline \multicolumn{2}{|l|}{ Kalina cycle subsystem } \\
\hline Isentropic efficiency of Pump 1 & $98 \%$ \\
\hline Pressure losses in each heat exchanger in Kalina cycle & 1 bar \\
\hline Minimum temperature differences in the evaporator & $6 \mathrm{~K}$ \\
\hline Minimum temperature differences in the HTR & $5 \mathrm{~K}$ \\
\hline Minimum temperature differences in the condenser & $3 \mathrm{~K}$ \\
\hline Turbine isentropic efficiency & $87 \%$ \\
\hline Temperature of the oil at inlet of evaporator & $393 \mathrm{~K}$ \\
\hline Temperature of the oil at outlet of evaporator & $353 \mathrm{~K}$ \\
\hline \multicolumn{2}{|c|}{ Mass rate of ammonia-water mixture to evaporator $16.8 \mathrm{~kg} \mathrm{~s}^{-1}$} \\
\hline Turbine outlet pressure & 6.6 bar \\
\hline Cooling water inlet temperature & $278 \mathrm{~K}$ \\
\hline Ammonia content & $82 \%$ \\
\hline Turbine inlet pressure & 32 bar \\
\hline \multicolumn{2}{|l|}{ Temperature stabilized subsystem } \\
\hline Heat transfer efficiency of auxiliary heater & $80 \%$ \\
\hline Volume of thermal storage tank & $100 \mathrm{~m}^{3}$ \\
\hline Area of thermal storage tank & $100 \mathrm{~m}^{2}$ \\
\hline Overall heat transfer coefficient, U & $0.001 \mathrm{~kW} \mathrm{~m}^{-2} \mathrm{~K}^{-1}$ \\
\hline \multicolumn{2}{|l|}{ Solar collector subsystem $[55]$} \\
\hline Collector type & $\mathrm{S} 13$ \\
\hline Concentration ratio & 82 \\
\hline Peak collector efficiency & $68 \%$ \\
\hline Annual thermal efficiency & $53 \%$ \\
\hline Optical efficiency & $0.8 \%$ \\
\hline Aperture area per SCA & $545 \mathrm{~m}^{2}$ \\
\hline Total aperture area & $20710 \mathrm{~m}^{2}$ \\
\hline Monthly average insolation, $\mathrm{H}$ & 26.39 $\mathrm{MJ} \mathrm{m}^{-2} \mathrm{day}^{-1}$ \\
\hline
\end{tabular}




\section{Thermodynamic analyses}

\subsection{Conventional exergy and exergoeconomic analyses}

The first step in the advanced exergy and exergoeconomic analyses is exergy and exergoeconomic analyses. In order to assess the performance of a system from the viewpoint of the second law, it is essential to identify 'Fuel-Product-Loss' (F-P-L) for each component of the system. The product represents the desired output produced by the component or the overall system. The fuel indicates the resource consumed to create the product and is not necessarily restricted to be an actual fuel such as coal, oil, or natural gas. The losses show the exergy loss from the system. Exergy destruction rate, $\dot{E} x_{D, k}$, and exergy efficiency, $\varepsilon_{k}$, for each component of the system can be calculated as follows [48]:

$$
\begin{aligned}
& \dot{E} x_{D, k}=\dot{E} x_{F, k}-\dot{E} x_{P, k}-\dot{E} x_{L, k}, \\
& \varepsilon_{k}=\frac{\dot{E} x_{P, k}}{\dot{E} x_{F, k}}=1-\frac{\dot{E} x_{D, k}+\dot{E} x_{L, k}}{\dot{E} x_{P, k}},
\end{aligned}
$$

where $\dot{E} x_{F, k}$ and $\dot{E} x_{P, k}$ are the fuel and product exergy rates, respectively, and $\dot{E} x_{L, k}$ is the rate of exergy loss for the $k$ th component. $\dot{E} x$ refers to the sum of the physical and chemical exergy rates. The irreversibility ratio, $y_{D, k}$, and improvement potential, $I P_{k}$, of the $k \mathrm{th}$ component are defined as [49]:

$$
\begin{aligned}
y_{D, k} & =\frac{\dot{E} x_{D, k}}{\dot{E} x_{D, t o t}}, \\
I P_{k} & =\left(1-\varepsilon_{k}\right) \dot{E} x_{D, k} .
\end{aligned}
$$

Exergy balance for the overall system is:

$$
\dot{E} x_{F, t o t}=\dot{E} x_{P, t o t}+\sum_{k} \dot{E} x_{D, k}+\dot{E} x_{L, t o t} .
$$

Exergoeconomic analysis combines exergy analysis and economic principles to provide the system designer or operator with information not available through conventional energy analysis and economic evaluations [48]; the conventional exergoeconomic equation can be defined as follows. The cost balance at steady state condition is formulated as follows [50]:

$$
\sum_{\text {out }} \dot{C}_{k}=\sum_{\text {in }} \dot{C}_{k}+\dot{Z}_{k}
$$

Here, $\dot{C}$ is the cost rate according to inlet and outlet streams, and $\dot{Z}$ is the capital investment and operating and maintenance cost rate for the $k$ th component. In exergy costing, inlet and outlet exergy streams of matter $\left(\dot{E} x_{\text {in,out }}\right)$, power $(\dot{W})$, and heat transfer $\left(\dot{E} x_{q}\right)$ can be written as follows:

$$
\begin{aligned}
& \dot{C}_{\text {in }, \text { out }}=c_{\text {in }, \text { out }} \dot{E} x_{\text {in }, \text { out }}, \\
& \dot{C}_{w}=c_{w} \dot{W}, \\
& \dot{C}_{q}=c_{q} \dot{E} x_{q} .
\end{aligned}
$$

Here, $c_{\text {in,out }, w, q}$ indicates average costs per unit of exergy in $\$ \mathrm{~kJ}^{-1}$ for inlet (in), outlet (out), power $(w)$, and energy $(q)$, respectively:

$$
\begin{aligned}
& \dot{C}_{D, k}=c_{F, k} \dot{E} x_{D, k}, \\
& \dot{C}_{L, k}=c_{F, k} \dot{E} x_{L, k}, \\
& r_{k}=\frac{c_{p, k}-c_{F, k}}{c_{F, k}}, \\
& f_{k}=\frac{\dot{Z}_{k}}{\dot{Z}_{k}+\dot{C}_{D, k}+\dot{C}_{L, k}} .
\end{aligned}
$$

In Eq. (13), $r_{k}$ is relative cost difference, which expresses the relative increase in the average cost per exergy unit between fuel and product of the component. This difference is due to the cost rate associated with the investment cost $\left(\dot{Z}_{k}\right)$ and the cost rate of exergy destruction $\left(\dot{C}_{D, k}\right)$ [48]. The exergoeconomic factor, $f_{k}$, is a parameter which expresses the relative importance of a component cost to the cost of exergy destruction and the loss associated with that component.

\subsection{Advanced exergetic analysis}

Irreversibility (entropy generation) limits the efficiency of energy conversion systems. The conventional exergy analysis methods are used to determine irreversibility, but these methods have some shortcomings; for example, in these methods, the reasons of irreversibility cannot be defined. Similarly, exergoeconomic methods combine the exergetic and economic parameters with each other to define the fuel, product, and destruction costs of the system. However, they do not enable us to show the relations between the economic parameters; therefore, advanced exergy based analyses should be applied to eliminate these deficiencies with high-certainty information that cannot be obtained by other approaches. In an advanced exergy analysis, the exergy destruction rate is divided into four parts: endogenous, exogenous, avoidable, and unavoidable exergy destruction rates. The exergy destruction of the $k$ th component depends on the exergy destructions associated with the irreversibility of the same component and also on the irreversibility of other components. The endogenous $\left(\dot{E} x_{D, k}^{E N}\right)$ exergy destruction rate occurs within the $k$ th component when it operates with its current efficiency and the remaining system components operate in an ideal way.

The exogenous exergy destruction rate $\left(\dot{E} x_{D, k}^{E X}\right)$ 
within the $k$ th component is defined as the irreversibility that occurs in other components and is obtained as the difference between real and endogenous exergy destruction of the $k$ th component. This splitting enables engineers to decide to consider whether the component or other system components in order to attain effective improvement in the overall performance:

$$
\dot{E} x_{D, k}^{E X}=\dot{E} x_{D, k}-\dot{E} x_{D, k}^{E N} .
$$

In more detail, the exergy destruction rate can be divided to the avoidable and unavoidable parts related to the system improvement potential. The exergy destruction that cannot be decreased due to today's technological constraints, such as availability and cost of materials, is the unavoidable $\left(\dot{E} x_{D, k}^{U N}\right)$ part of the exergy destruction. The avoidable $\left(\dot{E} x_{D, k}^{A V}\right)$ part of the exergy destruction represents the improvement potential concept and is calculated as the difference between real and unavoidable exergy destruction of the $k$ th component:

$$
\dot{E} x_{D, k}^{A V}=\dot{E} x_{D, k}-\dot{E} x_{D, k}^{U N} .
$$

The unavoidable endogenous exergy destruction rate $\left(\dot{E} x_{D, k}^{U N, E N}\right)$ is a part of the exergy destruction that cannot be decreased because of technical constraints for the $k$ th component. Also, the unavoidable exogenous exergy destruction rate $\left(\dot{E} x_{D, k}^{U N, E X}\right)$ is a part of the exergy destruction that cannot be decreased because of technical constraints in the remaining components of the overall system for the given structure. The unavoidable and avoidable exergy destruction is defined as the following equations [51]:

$$
\begin{aligned}
& \dot{E} x_{D, k}^{U N, E N}=\dot{E} x_{P, k}^{E N}\left(\frac{\dot{E} x_{D, k}}{\dot{E} x_{P, k}}\right), \\
& \dot{E} x_{D, k}^{U N, E X}=\dot{E} x_{D, k}^{U N}-\dot{E} x_{D, k}^{U N, E N} .
\end{aligned}
$$

The avoidable endogenous exergy destruction rate $\left(\dot{E} x_{D, k}^{A V, E N}\right)$ and the avoidable exogenous exergy destruction rate $\left(\dot{E} x_{D, k}^{A V, E X}\right)$ are presented as the following equations [51]:

$$
\begin{aligned}
& \dot{E} x_{D, k}^{A V, E N}=\dot{E} x_{D, k}^{E N}-\dot{E} x_{D, k}^{U N, E N}, \\
& \dot{E} x_{D, k}^{A V, E X}=\dot{E} x_{D, k}^{A V}-\dot{E} x_{D, k}^{A V, E N} .
\end{aligned}
$$

The value of $\dot{E} x_{D, k}^{A V, E N}$ can be decreased by elevation of the efficiency of the $k$ th component and the value of $\dot{E} x_{D, k}^{A V, E X}$ can be reduced using a structural improvement in the remaining components and the $k$ th component.

\subsection{Advanced exergoeconomic analysis}

In addition to the exergy destruction rate, the concepts of endogenous, exogenous, avoidable, and unavoidable parts can be applied to the investment cost and the exergy destruction cost rate. The endogenous and exogenous concepts are influenced by the internal operating specifications and the interactions between components, respectively.

The endogenous and exogenous cost rates of exergy destruction $\left(\dot{C}_{D, k}^{E N}\right.$ and $\left.\dot{C}_{D, k}^{E X}\right)$ that are associated with the $k$ th component are expressed as:

$$
\begin{aligned}
& \dot{C}_{D, k}^{E N}=c_{f, k} \dot{E} x_{D, k}^{E N}, \\
& \dot{C}_{D, k}^{E X}=c_{f, k} \dot{E} x_{D, k}^{E X},
\end{aligned}
$$

where $c_{f, k}$ expresses the fuel cost per exergy unit of the $k$ th component. Also, depending on whether the exergy destruction costs can be avoided or not, it is split into avoidable and unavoidable parts that can be presented as follows:

$$
\begin{gathered}
\dot{C}_{D, k}^{U N}=c_{f, k} \dot{E} x_{D, k}^{U N}, \\
\dot{C}_{D, k}^{A V}=c_{f, k} \dot{E} x_{D, k}^{A V} .
\end{gathered}
$$

The avoidable and unavoidable cost rates of exergy destruction are split into endogenous and exogenous parts, which are calculated by the following equations:

$$
\begin{aligned}
& \dot{C}_{D, k}^{U N, E N}=c_{f, k} \dot{E} x_{D, k}^{U N, E N} \\
& \dot{C}_{D, k}^{A V, E N}=c_{f, k} \dot{E} x_{D, k}^{A V, E N} \\
& \dot{C}_{D, k}^{U N, E X}=c_{f, k} \dot{E} x_{D, k}^{U N, E X} \\
& \dot{C}_{D, k}^{A V, E X}=c_{f, k} \dot{E} x_{D, k}^{A V, E X}
\end{aligned}
$$

The unavoidable investment cost flow rates $\left(\dot{Z}^{U N}\right)$ for turbine and pumps are assumed $90 \%$ and $60 \%$ of their capital investment costs, respectively, and for other components are calculated as follows [52]:

$$
\dot{Z}^{U N}=\left(\frac{\mathrm{PEC}^{U N}}{\mathrm{PEC}^{\text {real }}}\right)_{k} \times \dot{Z}_{k}^{\text {real }},
$$

where $\mathrm{PEC}_{k}^{U N}$ is the purchased equipment cost of the $k$ th component, associated with the unavoidable conditions that are explained in Table 5 [52]. In addition, the values of $\dot{Z}^{U N}$ for turbine and pumps are assumed $90 \%$ and $60 \%$ of their capital investment costs, respectively, and for other components are calculated as follows:

$$
\dot{Z}^{U N}=\left(\frac{\mathrm{PEC}^{U N}}{\mathrm{PEC}^{\text {real }}}\right)_{k} \times \dot{Z}_{k}^{\text {real }} .
$$


Theavoidable investment cost flow rate $\dot{Z}_{k}^{A V}$ is determined by subtracting the unavoidable investment cost flow from the real investment cost flow rate [31]:

$$
\dot{Z}_{k}^{A V}=\dot{Z}_{k}-\dot{Z}_{k}^{U N}
$$

Similarly, the exogenous investment cost flow rate is the difference between the real investment cost and the endogenous exergy cost flow rate [53]:

$$
\begin{aligned}
& \dot{Z}_{k}^{E N}=\dot{E}_{P, k}^{E N}\left(\frac{\dot{Z}}{\dot{E}_{P}}\right)_{k}, \\
& \dot{Z}_{k}^{E X}=\dot{Z}_{k}-\dot{Z}_{k}^{E N} .
\end{aligned}
$$

In addition, the exogenous parts of the investment cost and exergy destruction cost can be divided into the avoidable/unavoidable and endogenous/exogenous parts; these parameters are presented in the following [52]:

$$
\begin{aligned}
& \dot{Z}_{D, k}^{U N, E N}=\dot{E} x_{P, k}^{E N}\left(\frac{\dot{Z}^{*}}{\dot{E} X_{P}}\right)_{k}^{U N}, \\
& \left(\frac{\dot{Z}^{*}}{\dot{E} X_{P}}\right)_{k}^{U N}=\left(\frac{\dot{Z}^{U N}}{\dot{E} X_{P}^{\text {real }}}\right)_{k}, \\
& \dot{Z}_{k}^{U N, E X}=\dot{Z}_{k}^{U N}-\dot{Z}_{k}^{U N, E N}, \\
& \dot{Z}_{k}^{A V, E N}=\dot{Z}_{k}^{E N}-\dot{Z}_{k}^{U N, E N}, \\
& \dot{Z}_{k}^{A V, E X}=\dot{Z}_{k}^{E X}-\dot{Z}_{k}^{U N, E X} .
\end{aligned}
$$

Also, the modified exergoeconomic factor $\left(f_{k}^{A V, E N}\right)$ is defined as the major cost source associated with the component of the system, and is determined as follows [41]:

$$
f_{k}^{A V, E N}=\frac{\dot{Z}_{k}^{A V, E N}}{\dot{C}_{k}^{A V, E N}}=\frac{\dot{Z}_{k}^{A V, E N}}{\dot{C}_{k}^{A V, E N}+\dot{Z}_{k}^{A V, E N}} .
$$

Another parameter that determines the percentage of the avoidable endogenous part the current technological and economic environment is the total cost-savings potential $\left(p_{k}\right)$, which is defined as follows [41]:

$$
p_{k}=\frac{\dot{C}_{k}^{A V, E N}}{\dot{C}_{t o t, k}}=\frac{\dot{C}_{D, k}^{A V, E N}+\dot{Z}_{k}^{A V, E N}}{\dot{C}_{D, k}+\dot{Z}_{k}} .
$$

\section{Validation}

The Kalina cycle of the present work is taken from the investigation of Ogrisecks [54] for validation purposes. The relative differences among the eight properties of the present work and reference investigation are

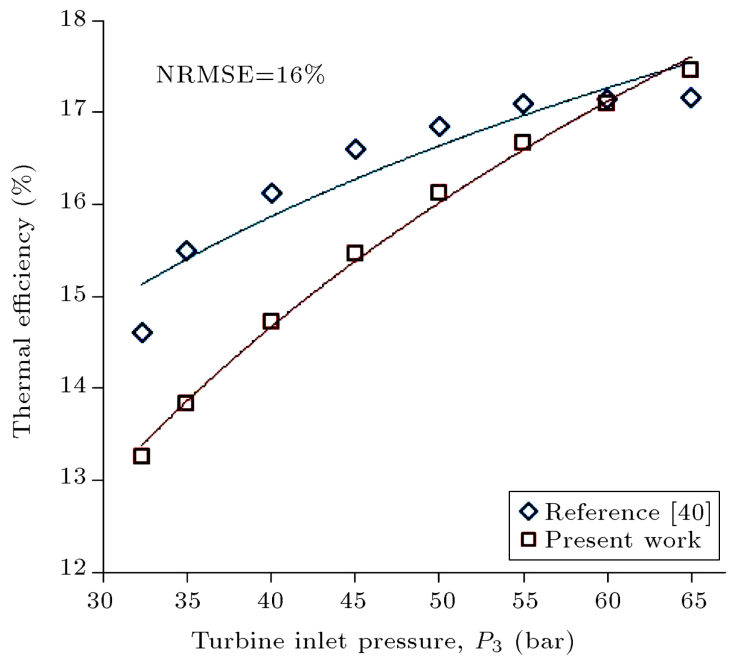

Figure 2. Validation of the present work by investigation result of Ogriseck [54].

calculated for each point of the cycle. These properties are temperature, pressure, quality, ammonia concentration, enthalpy, entropy, volume, and mass rates. The maximum average relative difference between all properties is determined by about $6.78 \%$. In addition, the variation of cycle thermal efficiency with the turbine inlet temperature is compared with the available data of the reference work. As shown in Figure 2, there is a good agreement between the results. Also, for this graph, the normalized root mean squared error is calculated $16 \%$ that indicates the reasonable agreement. The thermodynamic properties in Reference work [54] are taken from the software EBSILON_Professional, Version 7.01 Beta-Release, from Evonik Energy Services GmbH while the properties of the present work are calculated using the EES software.

\section{Results and discussion}

In this section, the conventional exergoeconomic analysis of a Kalina cycle integrated with PTSCs is carried out to obtain the exergoeconomic parameters for each component. It is assumed that the system is located in Semnan City (35.917 N, 53.917 E), Iran. System modeling is conducted based on maximum daily insolation incident on horizontal surface, which occurs on June 29 at 12:00. According to conventional exergoeconomic analysis, the exergoeconomic factor indicates the relationship between the energy efficiencies and the capital investment costs of the equipment. A low exergoeconomic factor indicates that efficiency improvement of the component should be considered by increasing the capital investment and its performance can be signally improved by capital investment into highly efficient design.

Table 2 indicates the major exergy and exergoeconomic parameters for each component of the solar 
Table 2. Exergetic and exergoeconomic parameters of the system.

\begin{tabular}{|c|c|c|c|c|c|c|c|c|c|c|c|c|}
\hline Component & $\begin{array}{c}\dot{\boldsymbol{E}} \boldsymbol{x}_{F} \\
(\mathrm{~kW})\end{array}$ & $\begin{array}{c}\dot{\boldsymbol{E}} \boldsymbol{x}_{P} \\
(\mathbf{k W})\end{array}$ & $\begin{array}{c}\dot{\boldsymbol{E}} \boldsymbol{x}_{D} \\
(\mathbf{k W})\end{array}$ & $\begin{array}{c}\varepsilon \\
(\%)\end{array}$ & $\begin{array}{c}y_{D, K} \\
(\%)\end{array}$ & $\begin{array}{c}\text { IP } \\
(\mathrm{kW})\end{array}$ & $\begin{array}{c}c_{f} \\
\left(\$ \mathbf{M J}^{-1}\right)\end{array}$ & $\begin{array}{c}c_{p} \\
\left(\$ \mathbf{M J}^{-1}\right)\end{array}$ & $\begin{array}{c}\dot{C}_{D} \\
\left(\$ \mathrm{~h}^{-1}\right)\end{array}$ & $\begin{array}{c}\dot{Z} \\
\left(\$ h^{-1}\right)\end{array}$ & $\begin{array}{c}f \\
(\%)\end{array}$ & $\begin{array}{c}r \\
(\%)\end{array}$ \\
\hline Auxiliary heater & 6161 & 2021 & 4140 & 0.3 & 22.8 & 3741.7 & 1.5 & 19 & 22 & 105.4 & 82.73 & 1186 \\
\hline PTSC & 14431 & 4891 & 9540 & 0.3 & 52.6 & 9540.0 & 0 & 47.1 & 0 & 829.1 & 100 & infinity \\
\hline Condenser & 622.4 & 481.8 & 140.6 & 0.8 & 0.8 & 140.6 & 112.4 & 234.7 & 56.9 & 155.1 & 73.15 & 108.7 \\
\hline HT recuperator & 397.1 & 264.8 & 132.3 & 0.7 & 0.7 & 132.3 & 111.9 & 177.6 & 53.3 & 9.4 & 14.99 & 58.75 \\
\hline LT recuperator & 459.1 & 148 & 311.1 & 0.3 & 1.7 & 311.1 & 112.4 & 381.1 & 125.9 & 17.2 & 12.03 & 239 \\
\hline Mixer & 3708 & 3689 & 19 & 1 & 0.1 & 19.0 & 111.9 & 112.4 & 7.6 & 0 & 0 & 0.51 \\
\hline Pump 1 & 89.8 & 75.1 & 14.7 & 0.4 & 0.1 & 53.8 & 165 & 272.2 & 8.7 & 20.3 & 70 & 65.01 \\
\hline Pump 2 & 91.4 & 37.6 & 53.8 & 0.8 & 0.3 & 25.1 & 165 & 552.8 & 32 & 20.5 & 39.08 & 235 \\
\hline Pump 3 & 45 & 19.9 & 25.1 & 0.4 & 0.1 & 14.7 & 165 & 567.7 & 14.9 & 13.9 & 48.2 & 244.1 \\
\hline Separator & 6609 & 6609 & 0 & 1 & 0 & 0.0 & 111.9 & 111.9 & 0 & 0 & 0 & 0 \\
\hline Thermal storage tank & 20611 & 20184 & 424.3 & 1 & 2.3 & 424.3 & 49.4 & 50.6 & 75.5 & 14.3 & 15.9 & 2.51 \\
\hline Turbine & 2504 & 2207 & 296.2 & 0.9 & 1.6 & 296.2 & 111.9 & 165 & 119.3 & 302.9 & 71.75 & 47.49 \\
\hline Evaporator & 6542 & 3513 & 3029 & 0.5 & 16.7 & 3029.0 & 46.6 & 91.7 & 508 & 62.8 & 11.01 & 96.88 \\
\hline
\end{tabular}

Kalina cycle. The largest value of exergoeconomic factor $f$ belongs to PTSC (100\%), in which the IP is maximum value among all components $(9540 \mathrm{~kW})$, indicating that the cost saving in the entire system cannot be achieved by improving the PTSC efficiency. Also, the PTSC has the highest value of exergy destruction rate $(9540 \mathrm{~kW})$, because solar energy with high quality heats a fluid with low temperature and the heat transfer at large temperature differences increases the irreversibility in it. Hence, attempt should be made to reduce this exergy destruction rate. However, there are many material constraints that play an important role in construction and operation condition.

The second most important component in the exergoeconomic analysis of the solar Kalina cycle is evaporator because of its high value of cost rate $\left(\dot{C}_{D, k}+\right.$ $\left.\dot{Z}_{k}\right)$; also, the value of exergoeconomic factor $f$ for the evaporator is very low, about $11.01 \%$, which is due to the high cost rate of exergy destruction in the evaporator. Therefore, efficiency improvement of this component should be considered by increasing the capital investment, and its performance can be signally improved by capital investment into highly efficient design. In addition, the relative cost difference has an influential role in optimization and evaluation of the system component and depicts the relative growth in the exergy product cost of a component according to its fuel exergy cost. The PTSC has infinite relative cost difference $r$ and the separator and mixer have the minimum ones ( 0 and 0.0051 , respectively). The prices for the exergy rate in a component are described with the product and fuel exergy cost values. Pump 2 has the maximum product cost rate $\left(552.8 \$ \mathrm{MJ}^{-1}\right)$, and the auxiliary heater has the minimum product cost rate $\left(19 \$ \mathrm{MJ}^{-1}\right)$. Pumps have the maximum fuel cost rate $\left(165 \$ \mathrm{MJ}^{-1}\right)$ and the PTSC has zero value of fuel cost rate. Table 2 shows the detailed results of the conventional exergy and exergoeconomic study. The results of the advanced exergetic and exergoeconomic analyses of the system may be listed as follows.

\subsection{Advanced exergy analysis}

The advanced exergy analysis is carried out based on the assumptions listed in Table 3 . Table 4 shows the results of the advanced exergetic analysis for the Kalina cycle. For the better analysis of the system, we should focus on the avoidable exergy destruction instead of total exergy destruction; because we cannot reduce the unavoidable exergy destruction. Since the operation of any component is dependent on the other ones, it is important to know how improvement of one component will affect the other component. Therefore, the values of endogenous and exogenous exergy destruction should be compared for each component.

However, for the auxiliary heater, the value of the exogenous exergy destruction is maximum $(4079.95 \mathrm{~kW})$, indicating that the exergy destruction of this component is related to design and operation condition of other components. Also, the exogenous exergy destruction of condenser and thermal storage tank is negative, that conflicts with entropy generation theory. Thus, increasing the efficiencies of the remaining components will not decrease exogenous exergy destruction, but actually increases it. The PTSC is the component that should be improved first, because the endogenous exergy destruction of the PTSC is higher than its exogenous exergy destruction; also, the value of its endogenous avoidable exergy destruction $(947.75 \mathrm{~kW})$ is the highest among all components; in order to reduce the PTSC exergy destruction rate, 
Table 3. Assumptions used as the theoretical and unavoidable conditions [26,29].

\begin{tabular}{lll}
\hline Component & Theoretical conditions & Unavoidable conditions \\
\hline Auxiliary heater & $\eta=100 \%$ & $\eta=99.5 \%$ \\
PTSC & $\eta=100 \%$ & $\eta=73 \%$ \\
Condenser & $\Delta p=0, \Delta T_{\min }=0$ & $\Delta p=0, \Delta T_{\min }=1$ \\
HT recuperator & $\Delta p=0, \Delta T_{\min }=0$ & $\Delta p=0, \Delta T_{\min }=3$ \\
LT recuperator & $\Delta p=0, \Delta T_{\min }=0$ & $\Delta p=0, \Delta T_{\min }=3$ \\
Pump 1 & $\eta_{\text {is }}=100 \%$ & $\eta_{\text {is }}=95 \%$ \\
Pump 2 & $\eta_{\text {is }}=100 \%$ & $\eta_{\text {is }}=95 \%$ \\
Pump 3 & $\eta_{\text {is }}=100 \%$ & $\eta_{\text {is }}=95 \%$ \\
Thermal storage tank & $U=0$ & $U=0$ \\
Turbine & $\eta_{\text {is }}=100 \%$ & $\eta_{\text {is }}=97 \%$ \\
Evaporator & $\Delta p=0, \Delta T_{\text {min }}=0$ & $\Delta p=0, \Delta T_{\min }=1$ \\
\hline
\end{tabular}

Table 4. Advanced exergy destruction rates of the system.

\begin{tabular}{|c|c|c|c|c|c|c|c|c|c|}
\hline Component & $\begin{array}{c}\dot{\boldsymbol{E}} \boldsymbol{x}_{D, k} \\
(\mathrm{~kW})\end{array}$ & $\begin{array}{c}\dot{\boldsymbol{E}} \boldsymbol{x}_{D, k}^{E N} \\
(\mathbf{k W})\end{array}$ & $\begin{array}{c}\dot{E} \boldsymbol{x}_{D, k}^{E X} \\
(\mathbf{k W})\end{array}$ & $\begin{array}{c}\dot{\boldsymbol{E}} \boldsymbol{x}_{D, k}^{U N} \\
(\mathrm{~kW})\end{array}$ & $\begin{array}{c}\dot{\boldsymbol{E}} \boldsymbol{x}_{D, k}^{A V} \\
(\mathbf{k W})\end{array}$ & $\begin{array}{c}\dot{\boldsymbol{E}} \boldsymbol{x}_{D, k}^{U N, E N} \\
(\mathrm{~kW})\end{array}$ & $\begin{array}{c}\dot{\boldsymbol{E}} \boldsymbol{x}_{D, k}^{U N, E X} \\
(\mathrm{~kW})\end{array}$ & $\begin{array}{c}\dot{\boldsymbol{E}} \boldsymbol{x}_{D, k}^{A V, \boldsymbol{E} N} \\
(\mathbf{k W})\end{array}$ & $\begin{array}{c}\dot{\boldsymbol{E}} \boldsymbol{x}_{D, k}^{A V, \boldsymbol{E} X} \\
(\mathrm{~kW})\end{array}$ \\
\hline Auxiliary heater & 4140 & 60.05 & 4079.95 & 2077.37 & 2062.63 & 43.26 & 2034.12 & 16.79 & 2045.83 \\
\hline PTSC & 9540 & 7496.86 & 2043.14 & 7482.50 & 2057.50 & 6549.12 & 933.38 & 947.75 & 1109.76 \\
\hline Condenser & 141.3 & 185.22 & -43.92 & 180.56 & -39.26 & 166.94 & 13.62 & 18.28 & -57.54 \\
\hline HT recuperator & 132.3 & 115.49 & 16.81 & 116.39 & 15.91 & 103.26 & 13.13 & 12.24 & 3.67 \\
\hline LT recuperator & 313.4 & 159.58 & 153.82 & 47.12 & 266.28 & 42.18 & 4.95 & 117.40 & 148.87 \\
\hline Pump 1 & 14.65 & 13.28 & 1.37 & 3.05 & 11.60 & 2.99 & 0.07 & 10.29 & 1.31 \\
\hline Pump 2 & 53.81 & 43.89 & 9.92 & 44.95 & 8.86 & 43.89 & 1.06 & 0.01 & 8.85 \\
\hline Pump 3 & 25.13 & 25.03 & 0.10 & 20.73 & 4.40 & 20.49 & 0.24 & 4.54 & -0.14 \\
\hline Thermal storage tank & 424.3 & 650.86 & -226.56 & 398.84 & 25.46 & 432.82 & -33.98 & 218.04 & -192.57 \\
\hline Turbine & 296.2 & 289.83 & 6.37 & 60.10 & 236.10 & 60.64 & -0.54 & 229.19 & 6.91 \\
\hline Evaporator & 3029 & 2504.57 & 524.43 & 2424.97 & 604.03 & 2374.91 & 50.07 & 129.67 & 474.36 \\
\hline
\end{tabular}

improving the PTSC itself has more importance than improving other components.

Based on value of endogenous avoidable exergy destruction, the turbine is the next component that has the highest value. It should be noticed that in the thermal storage tank, the value of $\dot{E} x_{D, k}^{A V, E X}$ related to the remaining components is negative that shows by improving the remaining components, the overall contribution will increase the exergy destruction of thermal storage tank by $192.57 \mathrm{~kW}$. The evaporator is the next component to be improved. Although $\dot{E} x_{D}^{A V, E X}$ in the evaporator is higher than $\dot{E} x_{D, k}^{A V, E N}$, the amount of $\dot{E} x_{D}^{A V, E N}$ is also high (129.6 kW). Therefore, the total exergy destruction rate of the evaporator can be decreased through improvement in both the evaporator itself and other components. The condenser and auxiliary heater are the fifth and sixth components that should be focused for improvement, which have $18.3 \mathrm{~kW}$ and $16.8 \mathrm{~kW}$ endogenous avoidable exergy destruction values, respectively; also, as indicated, the highest exogenous avoidable exergy destruction is due to the auxiliary heater $(4079.95 \mathrm{~kW})$. Thus, its total exergy destruction can be reduced significantly through improvement in the remaining components.

\subsection{Advanced exergoeconomic analysis}

Through an advanced exergoeconomic analysis, we can provide additional information for the conventional exergoeconomic analysis to improve design and operation of the system. The results of advanced exergoeconomic analysis are summarized in Table 5. It shows that, except for the auxiliary heater, the endogenous exergy destruction cost rates are greater than the exogenous exergy destruction cost rates of the components. This result indicates that the interactions among components do not affect the cost of exergy destruction significantly. In addition, the auxiliary heater is more affected by the other components; therefore, by decreasing the exergy destruction of the other components, we can reduce the exergy destruction costs of these components.

It can be seen in Table 5 that the exergy de- 
Table 5. Advanced exergy destruction cost rates of the system.

\begin{tabular}{|c|c|c|c|c|c|c|c|c|c|}
\hline Component & $\begin{array}{c}\dot{C}_{D, k} \\
\left(\$ \mathbf{h}^{-1}\right)\end{array}$ & $\begin{array}{c}\dot{C}_{D, k}^{E N} \\
\left(\$ \mathbf{h}^{-1}\right)\end{array}$ & $\begin{array}{c}\dot{C}_{D, k}^{E X} \\
\left(\$ \mathbf{h}^{-1}\right)\end{array}$ & $\begin{array}{c}\dot{C}_{D, k}^{U N} \\
\left(\$ \mathbf{h}^{-1}\right)\end{array}$ & $\begin{array}{c}\dot{C}_{D, k}^{A V} \\
\left(\$ \mathbf{h}^{-1}\right)\end{array}$ & $\begin{array}{c}\dot{C}_{D, k}^{U N, E N} \\
\left(\$ \mathbf{h}^{-1}\right)\end{array}$ & $\begin{array}{c}\dot{C}_{D, k}^{U N, E X} \\
\left(\$ \mathbf{h}^{-1}\right)\end{array}$ & $\begin{array}{c}\dot{C}_{D, k}^{A V, E N} \\
\left(\$ \mathrm{~h}^{-1}\right)\end{array}$ & $\begin{array}{c}\dot{C}_{D, k}^{A V, E X} \\
\left(\$ \mathrm{~h}^{-1}\right)\end{array}$ \\
\hline Auxiliary heater & 22.01 & 0.32 & 21.69 & 11.05 & 10.97 & 0.23 & 10.82 & 0.09 & 10.88 \\
\hline PTSC & 0.00 & 0.00 & 0.00 & 0.00 & 0.00 & 0.00 & 0.00 & 0.00 & 0.00 \\
\hline Condenser & 53.16 & 69.68 & -16.52 & 67.92 & -14.77 & 62.80 & 5.12 & 6.88 & -21.65 \\
\hline HT recuperator & 49.53 & 43.24 & 6.29 & 43.58 & 5.96 & 38.66 & 4.92 & 4.58 & 1.38 \\
\hline LT recuperator & 117.90 & 60.03 & 57.87 & 17.73 & 100.17 & 15.87 & 1.86 & 44.17 & 56.01 \\
\hline Pump 1 & 8.23 & 7.46 & 0.77 & 1.71 & 6.51 & 1.68 & 0.04 & 5.78 & 0.73 \\
\hline Pump 2 & 30.22 & 24.65 & 5.57 & 25.24 & 4.98 & 24.65 & 0.60 & 0.00 & 4.97 \\
\hline Pump 3 & 14.11 & 14.06 & 0.06 & 11.64 & 2.47 & 11.51 & 0.14 & 2.55 & -0.08 \\
\hline Thermal storage tank & 71.62 & 109.87 & -38.24 & 67.33 & 4.30 & 73.06 & -5.74 & 36.81 & -32.51 \\
\hline Turbine & 110.90 & 108.51 & 2.38 & 22.50 & 88.40 & 22.70 & -0.20 & 85.81 & 2.59 \\
\hline Evaporator & 467.69 & 386.72 & 80.97 & 374.43 & 93.26 & 366.70 & 7.73 & 20.02 & 73.24 \\
\hline
\end{tabular}

struction cost of PTSC is zero, which owes to the zero amount of exergy fuel cost. Also, the highest endogenous exergy destruction cost is due to the evaporator $\left(386.72 \$ \mathrm{~h}^{-1}\right.$ ), followed by the thermal storage tank $\left(109.87 \$ \mathrm{~h}^{-1}\right)$, turbine $\left(108.51 \$ \mathrm{~h}^{-1}\right)$, condenser $\left(69.68 \$ \mathrm{~h}^{-1}\right)$, and LT recuperator $(60.03$ $\left.\$ \mathrm{~h}^{-1}\right)$, respectively, which indicates that the exergy destruction cost rates of these components can be reduced by increasing the exergy efficiency of the components. The next conclusion is confirmed by the negative amount of $\dot{C}_{D}^{E X}$ in the condenser $(-16.52 \$$ $\left.\mathrm{h}^{-1}\right)$ and thermal storage tank $\left(-38.24 \$ \mathrm{~h}^{-1}\right)$ that indicates the reversible relation between exergy destruction cost rate of these components and efficiency of other components. It is clearly observed that the values of $\dot{C}_{D}^{A V}$ in the LT recuperator, evaporator, and turbine are more than those in other components that signifies the improvement potentials of these components, while the unavoidable part of exergy destruction cost rates of evaporator, thermal storage tank, and condenser are in high level.

The economic improvement potential of elements is determined by evaluation of their avoidable endogenous exergy destruction cost rates. In this study, the highest value of $\dot{C}_{D}^{A V, E N}$ is of the turbine $(85.81 \$$ $\left.\mathrm{h}^{-1}\right)$, followed by LT recuperator $\left(44.17 \$ \mathrm{~h}^{-1}\right)$, and thermal storage tank $\left(36.81 \$ \mathrm{~h}^{-1}\right)$. This fact implies that by improving these components, the system exergy destruction cost rate can be reduced significantly and the components must be considered themselves, instead of other components. It should be noticed that the values of $\dot{C}_{D}^{E X}$ in thermal storage tank (-38.24 $\left.\$ \mathrm{~h}^{-1}\right)$ and condenser $\left(-16.52 \$ \mathrm{~h}^{-1}\right)$ are negative, demonstrating that if the performance of remaining components rises, the exergy destruction cost rate of these components will increase. The evaporator has the highest value of $\dot{C}_{D}^{A V, E N}\left(73.24 \$ \mathrm{~h}^{-1}\right)$ and we can reduce the sizable portion of its exergy destruc- tion cost by improving exergy efficiency of the other component. Also, $\dot{C}_{D}^{A P, E X}$ in LT recuperator is huge $\left(56.01 \$ \mathrm{~h}^{-1}\right)$ in comparison with other components, associated with the exergy destruction cost rate of other components. About the auxiliary heater, the results show that the amount of $\dot{C}_{D}^{E N}$ is around zero because the exergy destruction cost rate of auxiliary heater is dependent on other components and only half of $\dot{C}_{D}^{E X}$ can be avoided by using new technologies in other components.

Another parameter in advanced exergoeconomic analyses is the capital investment cost rate. Table 6 displays the breakdown of capital investment cost rate for each element. For the auxiliary heater, $\dot{Z}^{E N}$ is lower than the exogenous one, indicating that the capital investment cost of the auxiliary heater is strongly associated with those of other components; thus, for reduction of investment cost rate of this component, it must be focused on other components. For other components, the endogenous capital investment cost rate has the greatest partition in capital investment cost rate; this fact indicates that in the capital investment cost analysis, the components are more important than the interaction between the components.

The PTSC has the highest value of endogenous capital investment cost rate $\left(649.9 \$ \mathrm{~h}^{-1}\right)$ followed by turbine $\left(298.75 \$ \mathrm{~h}^{-1}\right)$ and condenser $\left(154.95 \$ \mathrm{~h}^{-1}\right)$. The result also shows that the values of unavoidable capital investment cost rate for most components are higher than their avoidable capital investment cost rates because of the technology cost limitation.

The PTSC, turbine, and condenser have the greatest contribution to $\dot{Z}^{U N}$ with the values of 682.91 , 272.61 , and $72.04 \$ \mathrm{~h}^{-1}$, respectively; also, the highest amounts of avoidable capital investment cost rate are associated with the PTSC (146.2 $\left.\$ \mathrm{~h}^{-1}\right)$ and condenser $\left(82.8 \$ \mathrm{~h}^{-1}\right)$, indicating the improvement potential concept of these components. It is clearly observed that 
Table 6. Advanced investment cost rates of the system.

\begin{tabular}{|c|c|c|c|c|c|c|c|c|c|}
\hline Component & $\begin{array}{c}\dot{Z}_{k} \\
\left(\$ \mathbf{h}^{-1}\right)\end{array}$ & $\begin{array}{c}\dot{Z}_{k}^{E N} \\
\left(\$ \mathrm{~h}^{-1}\right)\end{array}$ & $\begin{array}{c}\dot{Z}_{k}^{E X} \\
\left(\$ \mathrm{~h}^{-1}\right)\end{array}$ & $\begin{array}{c}\dot{Z}_{k}^{U N} \\
\left(\$ \mathbf{h}^{-1}\right)\end{array}$ & $\begin{array}{c}\dot{Z}_{k}^{A V} \\
\left(\$ \mathrm{~h}^{-1}\right)\end{array}$ & $\begin{array}{c}\dot{Z}_{k}^{U N, E N} \\
\left(\$ \mathbf{h}^{-1}\right)\end{array}$ & $\begin{array}{l}\dot{Z}_{k}^{U N, E X} \\
\left(\$ \mathbf{h}^{-1}\right)\end{array}$ & $\begin{array}{l}\dot{Z}_{k}^{A V, E N} \\
\left(\$ \mathrm{~h}^{-1}\right)\end{array}$ & $\begin{array}{l}\dot{Z}_{k}^{A V, E X} \\
\left(\$ \mathrm{~h}^{-1}\right)\end{array}$ \\
\hline Auxiliary heater & 22.83 & 0.34 & 22.50 & 13.22 & 9.62 & 0.20 & 13.02 & 0.14 & 9.48 \\
\hline PTSC & 829.08 & 649.91 & 179.17 & 682.91 & 146.17 & 535.33 & 147.58 & 114.58 & 31.59 \\
\hline Condenser & 154.87 & 154.95 & -0.08 & 72.04 & 82.83 & 72.08 & -0.04 & 82.87 & -0.04 \\
\hline HT recuperator & 9.40 & 7.62 & 1.78 & 8.82 & 0.58 & 7.14 & 1.67 & 0.47 & 0.11 \\
\hline LT recuperator & 17.38 & 11.10 & 6.28 & 12.59 & 4.79 & 8.04 & 4.55 & 3.06 & 1.73 \\
\hline Pump 1 & 20.30 & 15.94 & 4.36 & 12.18 & 8.12 & 9.56 & 2.62 & 6.38 & 1.74 \\
\hline Pump 2 & 20.51 & 16.73 & 3.78 & 12.30 & 8.20 & 10.04 & 2.27 & 6.69 & 1.51 \\
\hline Pump 3 & 13.89 & 11.38 & 2.51 & 8.33 & 5.56 & 6.83 & 1.50 & 4.55 & 1.00 \\
\hline Thermal storage tank & 14.34 & 13.23 & 1.11 & 11.81 & 2.53 & 10.90 & 0.92 & 2.33 & 0.20 \\
\hline Turbine & 302.90 & 298.75 & 4.16 & 272.61 & 30.29 & 268.87 & 3.74 & 29.87 & 0.42 \\
\hline Evaporator & 62.82 & 53.24 & 9.58 & 58.94 & 3.88 & 49.95 & 8.98 & 3.29 & 0.59 \\
\hline
\end{tabular}

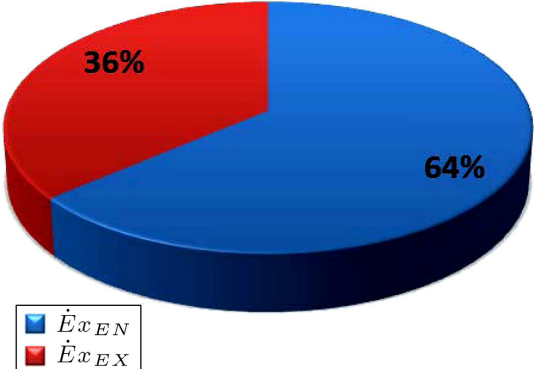

Figure 3. Endogenous and exogenous exergy destruction rates of the system.

the first component that should be considered is PTSC, because it is the highest among other components $\left(114.6 \$ \mathrm{~h}^{-1}\right)$, although its $\dot{Z}^{U N}$ is huge. Therefore, it has important role to reduce the capital investment cost of the system. The second important component in advanced capital investment cost analyses is the condenser of which the most capital investment cost rate is associated with the endogenous one. The next component that has appropriate $\dot{Z}^{A V, E N}$ is turbine, the value of which is equal to $29.9 \$ \mathrm{~h}^{-1}$. Also, $\dot{Z}^{A V, E X}$ of the PTSC and auxiliary heater has the highest level among other components, indicating that by improving the performance of other components, the capital investment cost of these components can decrease significantly.

Figures 3-5 reveal the results of advanced exergetic analyses for the entire system. As shown in Figure 3, the highest rate of exergy destruction is of endogenous exergy destruction (64\%), which demonstrates that the interactions of the system components have not trenchant influence on the exergy destruction of the entire system. Also, as Figure 4 displays, the improvement potential of the system, i.e. $\dot{C}^{A V}$ of the entire system, is only $29 \%$ because of economic and technological limitations. According to Figure 5, $32 \%$ of this improvement potential is related to the

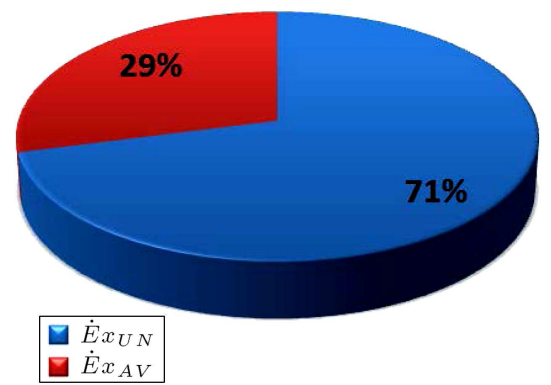

Figure 4. Avoidable and unavoidable exergy destruction rates of the system.

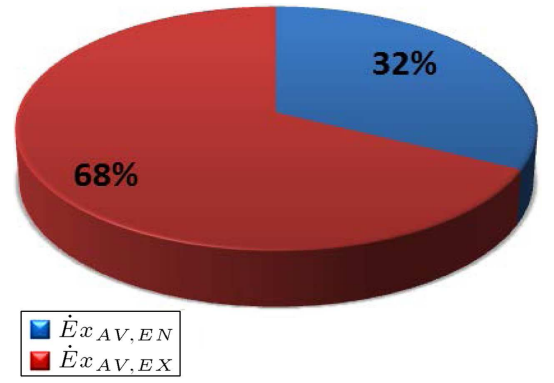

Figure 5. Endogenous avoidable and unavoidable exergy destruction rates of the system.

components and $68 \%$ is due to the interaction among the components.

Figures 6-8 present the result of advanced exergoeconomic study of the entire system. Based on Figure 6 , only $13 \%$ of the exergy destruction cost rates owe to the interactions of the components and $87 \%$ of exergy destruction cost rate belongs to the endogenous part of the exergy destruction cost rates.

Also, as shown in Figure 7, the contribution of $\dot{C}^{A V}$ to the entire exergy destruction cost rates of the system is $32 \%$, of which $68 \%$ is related to the avoidable endogenous part of the component and $32 \%$ is associated with the interactions of the components with the exergy destruction cost rate. 


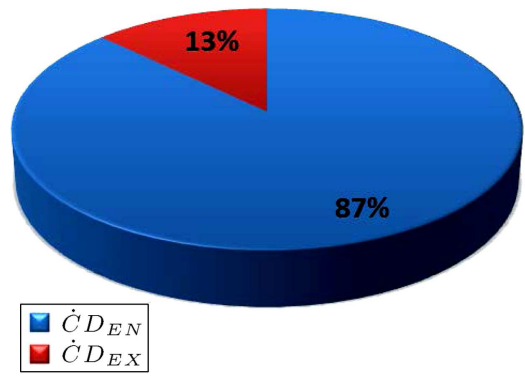

Figure 6. Endogenous and exogenous exergy destruction cost rates of the system.

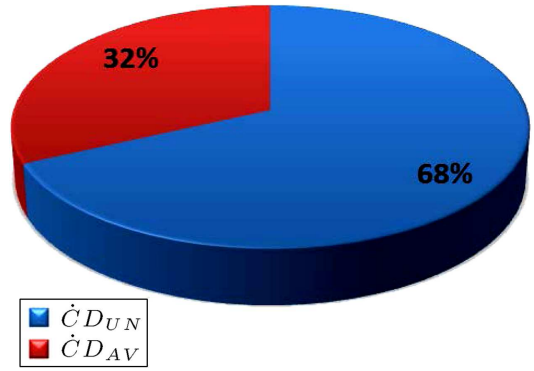

Figure 7. Avoidable and unavoidable exergy destruction cost rates of the system.

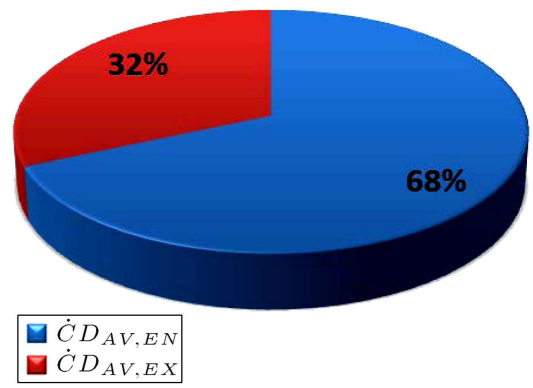

Figure 8. Endogenous avoidable and unavoidable exergy destruction cost rates of the system.

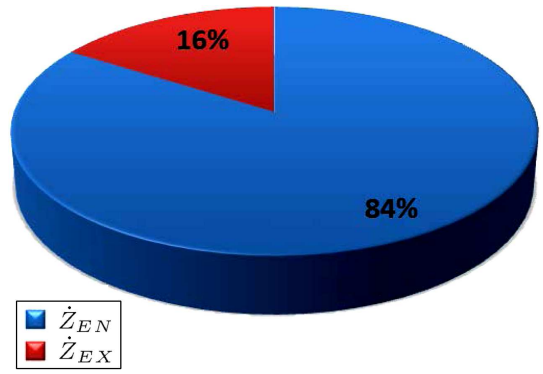

Figure 9. Endogenous and exogenous investment cost rates of the system.

As demonstrated in Figure 9, the component interactions have small contribution to the investment cost rates, so that $84 \%$ of the investment cost rates are associated with endogenous cost. Also, according to Figures 10 and $11, \dot{Z}^{A V}$ is only $21 \%$, of which $84 \%$ is endogenous; Figure 11 indicates that endogenous avoidable investment cost rates of the system are higher than its exogenous part.

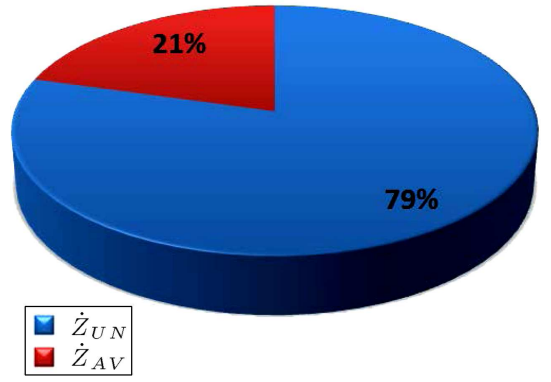

Figure 10. Avoidable and unavoidable investment cost rates of the system.

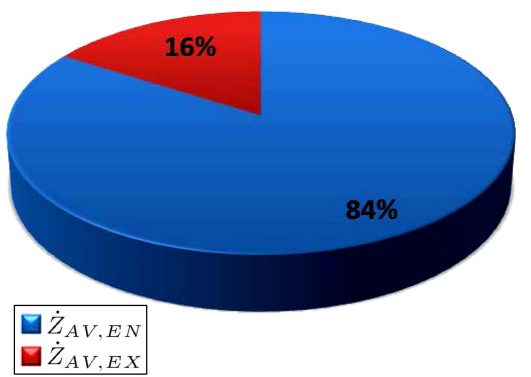

Figure 11. Endogenous avoidable and unavoidable investment cost rates of the system.

\section{Conclusions}

This study conducted the advanced exergoeconomic study for a Kalina system integrated with PTSC. The major conclusions drawn from the examined system indicate that the avoidable endogenous part of the entire system, regarding energy saving, is only $32 \%$, which means that component interactions are relatively high. Thus, the plant should be primarily improved by modifying the interaction operation of components. In addition, the avoidable endogenous of the system for the exergetic cost rate is more than its improvement potential for the investment cost rate. The major components for reduction of exergy destruction rate are PTSC, thermal storage tank, and turbine, respectively, while turbine, LP recuperator, and evaporator, respectively, with high levels of $\dot{C}_{D}^{A V, E N}$ should be considered from the cost saving viewpoint. Furthermore, the improvement potential of PTSC, condenser, and turbine, respectively, must be considered to decrease capital investment cost rates. This means that if the cost and energy saving is important at the start of the project, PTSC should be considered, while during the operation of the plant, the turbine should be considered from the cost saving viewpoint.

\section{Nomenclature}

$\begin{array}{ll}\dot{C} & \text { Cost rate, } \$ \mathrm{~h}^{-1} \\ c & \text { Cost per exergy unit, } \$ \mathrm{MJ}^{-1} \\ \dot{E} x & \text { Exergy rate, } \mathrm{kW}\end{array}$




\begin{tabular}{|c|c|}
\hline$e x$ & Specific exergy, $\mathrm{kJ} \mathrm{kg}^{-1}$ \\
\hline$f$ & Exergoeconomic factor, $\%$ \\
\hline$H$ & $\begin{array}{l}\text { Monthly average insolation, J } \\
\mathrm{m}^{-2} \mathrm{day}^{-1}\end{array}$ \\
\hline$h$ & Enthalpy, kJ kg-1 \\
\hline$I P$ & Improvement Potential \\
\hline$\dot{m}$ & Mass flow rate, $\mathrm{kg} \mathrm{s}^{-1}$ \\
\hline$P$ & Pressure, bar \\
\hline$p$ & total cost-savings potential $\%$ \\
\hline PEC & Purchased Equipment Cost, $\$$ \\
\hline PTSC & Parabolic-Trough Solar Collectors \\
\hline$q$ & Quality \\
\hline$\dot{Q}$ & Heat transfer rate, $\mathrm{kJ} \mathrm{s}^{-1}$ \\
\hline$r$ & Relative cost difference, $\%$ \\
\hline$s$ & Specific entropy, $\mathrm{kJ} \mathrm{kg}^{-1} \mathrm{~K}^{-1}$ \\
\hline $\mathrm{SCA}$ & Solar Collector Assemblies \\
\hline$T$ & Temperature, K \\
\hline$U$ & $\begin{array}{l}\text { Overall heat transfer coefficient, } \mathrm{kW} \\
\mathrm{m}^{-2} \mathrm{~K}^{-1}\end{array}$ \\
\hline$\dot{W}$ & Power, kW \\
\hline$x$ & Ammonia basic concentration \\
\hline$\dot{Z}$ & $\begin{array}{l}\text { Investment cost rate of components, } \\
\$ \mathrm{~h}^{-1}\end{array}$ \\
\hline
\end{tabular}

\section{Subscripts}

$\begin{array}{ll}A V & \text { Avoidable } \\ D & \text { Destruction } \\ E N & \text { Endogens } \\ E X & \text { Exogenous } \\ F & \text { Fuel } \\ \text { in } & \text { Input } \\ L & \text { Loss } \\ \text { net } & \text { Net } \\ \text { out } & \text { Output } \\ P & \text { Product } \\ q & \text { Heat } \\ \text { real } & \text { Real condition } \\ t o t & \text { Total } \\ U N & \text { Unavoidable } \\ w & \text { Work } \\ Y & \text { Irreversibility ratio }\end{array}$

\section{Greek letters}

\section{$\varepsilon \quad$ Exergy efficiency}

\section{References}

1. Kalina, A.I., Generation of Energy by Means of a Working Fluid, and Regeneration of a Working Fluid, Google Patents (1982).
2. Yari, M., Mehr, A., Zare, V., Mahmoudi, S. and Rosen, M. "Exergoeconomic comparison of TLC (trilateral Rankine cycle), ORC (organic Rankine cycle) and Kalina cycle using a low grade heat source", Energy, 83, pp. 712-722 (2015).

3. Usvika, R., Rifaldi, M. and Noor, A. "Energy and exergy analysis of Kalina cycle system (KCS) 34 with mass fraction ammonia-water mixture variation", $J$. Mech Sci Technol, 23(7), pp. 1871-1876 (2009).

4. Arslan, O. "Power generation from medium temperature geothermal resources: ANN-based optimization of Kalina cycle system-34", Energy, 36(5), pp. 2528-2534 (2011).

5. Campos Rodríguez, C.E., Escobar Palacio, J.C., Venturini, O.J., Silva Lora, E.E., Cobas, V.M., Marques dos Santos, D., Lofrano Dotto, F.R. and Gialluca, V. "Exergetic and economic comparison of ORC and Kalina cycle for low temperature enhanced geothermal system in Brazil", Appl. Therm. Eng. (2012).

6. Arslan, O. "Exergoeconomic evaluation of electricity generation by the medium temperature geothermal resources, using a Kalina cycle: Simav case study", Int. J. Therm. Sci., 49(9), pp. 1866-1873 (2010).

7. Koroneos, C.J. and Rovas, D.C. "Electricity from geothermal energy with the Kalina cycle an exergy approach", 7th Int. Conf. on Clean Electr. Power, pp. 423-428 (2007).

8. Shokati, N., Ranjbar, F. and Yari, M. "Exergoeconomic analysis and optimization of basic, dual-pressure and dual-fluid ORCs and Kalina geothermal power plants: A comparative study", Renew Energ., 83, pp. 527-542 (2015).

9. Zare, V. and Mahmoudi, S. "A thermodynamic comparison between organic Rankine and Kalina cycles for waste heat recovery from the gas turbine-modular helium reactor", Energy, 79, pp. 398-406 (2015).

10. Mohammadkhani, F., Ranjbar, F. and Yari, M. "A comparative study on the ammonia-water based bottoming power cycles: The exergoeconomic view point", Energy (2015).

11. Zare, V., Mahmoudi, S. and Yari, M. "On the exergoeconomic assessment of employing Kalina cycle for GT-MHR waste heat utilization", Energ. Convers. Manage., 90, pp. 364-374 (2015).

12. Lolos, P. and Rogdakis, E. "A Kalina power cycle driven by renewable energy sources", Energy, 34(4), pp. 457-464 (2009).

13. Sun, F., Ikegami, Y. and Jia, B. "A study on Kalina solar system with an auxiliary superheater", Renew Energ., 41, pp. 210-219 (2012).

14. Rogdakis, E. "Thermodynamic analysis, parametric study and optimum operation of the Kalina cycle", Int. J. Energ. Res., 20(4), pp. 359-370 (1996).

15. Sun, F., Zhou, W., Ikegami, Y., Nakagami, K. and $\mathrm{Su}, \mathrm{X}$. "Energy-exergy analysis and optimization of the solar-boosted Kalina cycle system 11 (KCS-11)", Renew Energ., 66, pp. 268-279 (2014). 
16. Shankar Ganesh, N. and Srinivas, T. "Design and modeling of low temperature solar thermal power station", Appl. Energ., 91(1), pp. 180-186 (2012).

17. Peng, S., Hong, H. and Jin, H. "Triple cycle for solar thermal power system adapted to periods with varying insolation", Energy, 60(0), pp. 129-138 (2013).

18. Mittelman, G. and Epstein, M. "A novel power block for CSP systems", Sol. Energy, 84(10), pp. 1761-1771 (2010).

19. Wang, J., Yan, Z., Zhou, E. and Dai, Y. "Parametric analysis and optimization of a Kalina cycle driven by solar energy", Appl. Therm. Eng. (2012).

20. Modi, A. and Haglind, F. "Performance analysis of a Kalina cycle for a central receiver solar thermal power plant with direct steam generation", Appl. Therm. Eng., 65(1-2), pp. 201-208 (2014).

21. Kelly, S., Tsatsaronis, G. and Morosuk, T. "Advanced exergetic analysis: Approaches for splitting the exergy destruction into endogenous and exogenous parts", Energy, 34(3), pp. 384-391 (2009).

22. Morosuk, T. and Tsatsaronis, G. "Advanced exergy analysis for chemically reacting systems-application to a simple open gas-turbine system", Int. J. Thermodyn., 12(3), pp. 105-111 (2010).

23. Şöhret, Y., Açıkkalp, E., Hepbasli, A. and Karakoc, T.H. "Advanced exergy analysis of an aircraft gas turbine engine: Splitting exergy destructions into parts", Energy (2015).

24. Tsatsaronis, G. and Morosuk, T. "Advanced exergetic analysis of a novel system for generating electricity and vaporizing liquefied natural gas", Energy 35(2), pp. 820-829 (2010).

25. Morosuk, T. and Tsatsaronis, G. "Comparative evaluation of LNG-based cogeneration systems using advanced exergetic analysis", Energy, 36(6), pp. 37713778 (2011).

26. Petrakopoulou, F., Tsatsaronis, G., Morosuk, T. and Carassai, A. "Conventional and advanced exergetic analyses applied to a combined cycle power plant", Energy, 41(1), pp. 146-152 (2012).

27. Boyaghchi, F.A. and Molaie, H. "Sensitivity analysis of exergy destruction in a real combined cycle power plant based on advanced exergy method", Energ. Convers. Manage., 99, pp. 374-386 (2015).

28. Boyaghchi, F.A. and Molaie, H. "Investigating the effect of duct burner fuel mass flow rate on exergy destruction of a real combined cycle power plant components based on advanced exergy analysis", Energ. Convers. Manage., 103, pp. 827-835 (2015).

29. Wang, L., Yang, Y., Morosuk, T. and Tsatsaronis, G. "Advanced thermodynamic analysis and evaluation of a supercritical power plant", Energies, 5(6), pp. 18501863 (2012).

30. Yamankaradeniz, N. "Thermodynamic performance assessments of a district heating system with geothermal by using advanced exergy analysis", Renew Energ., 85, pp. 965-972 (2016).
31. Aras, H. and Hepbasli, A. "Advanced exergy analysis of a trigeneration system with a diesel-gas engine operating in a refrigerator plant building", Energ. Buildings (2014).

32. Chen, J., Havtun, H. and Palm, B. "Conventional and advanced exergy analysis of an ejector refrigeration system", Appl. Energ., 144, pp. 139-151 (2015).

33. Esfahani, I.J., Lee, S. and Yoo, C. "Evaluation and optimization of a multi-effect evaporation-absorption heat pump desalination based conventional and advanced exergy and exergoeconomic analyses", Desalination, 359, pp. 92-107 (2015).

34. Keçebaş, A. and Gökgedik, H. "Thermodynamic evaluation of a geothermal power plant for advanced exergy analysis", Energy (2015).

35. Erbay, Z. and Hepbasli, A. "Application of conventional and advanced exergy analyses to evaluate the performance of a ground-source heat pump (GSHP) dryer used in food drying", Energ. Convers. Manage., 78, pp. 499-507 (2014).

36. Tsatsaronis, G. and Park, M.-H. "On avoidable and unavoidable exergy destructions and investment costs in thermal systems", Energ. Convers. Manage., 43(9), pp. 1259-1270 (2002).

37. Khoshgoftar Manesh, M., Navid, P., Blanco Marigorta, A., Amidpour, M. and Hamedi, M. "New procedure for optimal design and evaluation of cogeneration system based on advanced exergoeconomic and exergoenvironmental analyses", Energy, 59, pp. 314-333 (2013).

38. Cziesla, F., Tsatsaronis, G. and Gao, Z. "Avoidable thermodynamic inefficiencies and costs in an externally fired combined cycle power plant", Energy, 31(10), pp. 1472-1489 (2006).

39. Coskun, C., Oktay, Z. and Dincer, I. "Modified exergoeconomic modeling of geothermal power plants", Energy, 36(11), pp. 6358-6366 (2011).

40. Petrakopoulou, F., Tsatsaronis, G., Morosuk, T. and Carassai, A. "Advanced exergoeconomic analysis applied to a complex energy conversion system", J. Eng. Gas Turb. Power, 134(3), pp. 031801 (2012).

41. Tan, M. and Keçebaş, A. "Thermodynamic and economic evaluations of a geothermal district heating system using advanced exergy-based methods", Energ. Convers. Manage., 77, pp. 504-513 (2014).

42. Açıkkalp, E., Aras, H. and Hepbasli, A. "Advanced exergy analysis of an electricity-generating facility using natural gas", Energ. Convers. Manage., 82, pp. 146-153 (2014).

43. Mehrpooya, M. and Ansarinasab, H. "Advanced exergoeconomic evaluation of single mixed refrigerant natural gas liquefaction processes", J. Nat. Gas. Sci. Eng. (2015).

44. Mehrpooya, M. and Ansarinasab, H. "Advanced exergoeconomic analysis of the multistage mixed refrigerant systems", Energ. Convers. Manage., 103, pp. 705-716 (2015). 
45. Açıkkalp, E., Yucer, C.T., Hepbasli, A. and Karakoc, T.H. "Advanced low exergoeconomic (ALEXERGO) assessment of a building along with its heating system at various stages", Energ. Buildings, 87, pp. 66-73 (2015).

46. Gungor, A., Tsatsaronis, G., Gunerhan, H. and Hepbasli, A. "Advanced exergoeconomic analysis of a gas engine heat pump (GEHP) for food drying processes", Energ. Convers. Manage., 91, pp. 132-139 (2015).

47. Kalogirou, S.A. "A detailed thermal model of a parabolic trough collector receiver", Energy, 48(1), pp. 298-306 (2012).

48. Bejan, A. and Moran, M.J., Thermal Design and Optimization, Wiley (1996).

49. Rosen, M.A., Dincer, I. and Kanoglu, M. "Role of exergy in increasing efficiency and sustainability and reducing environmental impact", Energ. Policy., 36(1), pp. 128-137 (2008).

50. Tempesti, D. and Fiaschi, D. "Thermo-economic assessment of a micro CHP system fuelled by geothermal and solar energy", Energy (2013).

51. Petrakopoulou, F., Comparative Evaluation of Power Plants with $\mathrm{CO}_{2}$ Capture: Thermodynamic, Economic and Environmental Performance, Berlin Technical University, Institut für Energietechnik (2010).

52. Petrakopoulou, F., Tsatsaronis, G. and Morosuk, T. "Cost reduction strategies for an oxy-fuel power plant with $\mathrm{CO}_{2}$ capture: application of an advanced exergoeconomic analysis to an advanced zero emission plant", ASME 2011 International Mechanical Engi- neering Congress and Exposition, American Society of Mechanical Engineers, pp. 1063-1073 (2011).

53. Açıkkalp, E., Aras, H. and Hepbasli, A. "Advanced exergoeconomic analysis of a trigeneration system using a diesel-gas engine", Appl. Therm. Eng., 67(1), pp. 388-395 (2014).

54. Ogriseck, S. "Integration of Kalina cycle in a combined heat and power plant, a case study", Appl. Therm. Eng., 29(14), pp. 2843-2848 (2009).

55. Baghernejad, A. and Yaghoubi, M. "Exergy analysis of an integrated solar combined cycle system", Renew Energ., 35(10), pp. 2157-2164 (2010).

\section{Biographies}

Fateme Ahmadi Boyaghchi received a BS degree in Mechanical Engineering from IUST University, Iran, and MS and PhD degrees in Energy Conversion from IUST. Her specific research interests are solar-driven energy systems, environment, and conventional power plants. She has two books and numerous professional journal articles. She is currently Assistant Professor in the Faculty of Engineering at Alzahra University, Tehran, Iran.

Mahboobe Sabaghian received her BS in Mechanical Engineering from Semnan University, Semnan, Iran. She received her MS in Energy Systems Engineering from Alzara University, Tehran, Iran. Her major interests are solar energy systems and optimization. 